\title{
On the Road from Phenotypic Plasticity to Stem Cell Therapy
}

\author{
Lorraine Iacovitti \\ Department of Neuroscience, Director, Jefferson Stem Cell and Regenerative Neuroscience Center, Vickie and Jack Farber Institute for \\ Neuroscience, Thomas Jefferson University, Philadelphia, Pennsylvania 19107
}

In 1981, I published a paper in the first issue of The Journal of Neuroscience with my postdoctoral mentor, Richard Bunge. At that time, the long-standing belief that each neuron expressed only one neurotransmitter, known as Dale's Principle (Dale, 1935), was being hotly debated following a report by French embryologist Nicole Le Douarin showing that neural crest cells destined for one transmitter phenotype could express characteristics of another if transplanted to alternate sites in the developing embryo (Le Douarin, 1980). In the Bunge laboratory, we were able to more directly test the question of phenotypic plasticity in the controlled environment of the tissue culture dish. Thus, in our paper, we grew autonomic catecholaminergic neurons in culture under conditions which promoted the acquisition of cholinergic traits and showed that cells did not abandon their inherited phenotype to adopt a new one but instead were capable of dual transmitter expression. In this Progressions article, I detail the path that led to these findings and how this study impacted the direction I followed for the next 40 years. This is my journey from phenotypic plasticity to the promise of a stem cell therapy.

\section{Introduction}

I came of age in science at an exciting time: it was a decade after the pivotal discovery by Falck and Hillarp that neurons containing catecholamine neurotransmitters could be made to temporarily fluoresce when exposed to formaldehyde vapor (Falck, 1962). This technique, while ground-breaking, proved to be relatively impractical for experimentation. So, in 1974, it was my good fortune to join the prestigious laboratory of Donald Reis as a new $\mathrm{PhD}$ student at Cornell University Medical College... and to do so at a time when Tong Joh was there generating the "world's best" tyrosine hydroxylase (TH) antibodies and Virginia Pickel was perfecting the science of localizing those antibodies in catecholamine neurons. It was during those heady days when immunohistochemistry replaced histofluorescence that I learned to love all things catecholamine, a passion I never lost throughout my career.

But it was not until joining the laboratory of Drs. Richard and Mary Bunge at Washington University Medical School as a postdoctoral fellow that I began to actually manipulate catecholamine neurons. Landing in the Bunge laboratory, a

Received Feb. 19, 2021; revised Apr. 18, 2021; accepted Apr. 27, 2021.

I congratulate The Journal of Neuroscience on 40 fabulous years. Keep up the good work.

I gratefully acknowledge the funding agencies which have supported our work, including National Institute of Neurological Disorders and Stroke, National Institute of Aging, National Institute of Allergy and Infectious Disease, National Science Foundation, Michael J. Fox Foundation, Parkinson Council, Newell-DeValpine Foundation, Hassel Foundation, Tilker Foundation, Eizen Foundation, and the Ben Franklin Partnership.

I dedicate this retrospective to my mentors Dr. Richard Bunge and Dr. Donald Reis who left us much too soon. They taught me to ask the simple straightforward questions, to have fun in science, and to keep balance, enjoying all that life has to offer.

The author declares no competing financial interests.

Correspondence should be addressed to Lorraine lacovitti at Lorraine.iacovitti@jefferson.edu.

https://doi.org/10.1523/JNEUROSCI.0340-21.2021

Copyright $\odot 2021$ the authors warm and welcoming home to so many of us, was yet another stroke of luck. Dick, a pioneer and world's leading authority in nerve tissue culture, instilled in all of us, the F1 generation of nerve tissue culturists, a life-long zeal for the in vitro approach. This was no easy feat when you consider that, in 1980, we were still hand-molding and acid washing all of our own tissue culture dishes. Beyond the laboratory, I found myself surrounded at Washington University by an incredibly talented and collaborative group of neuroscientists assembled by Max Cowan, then the Chair of the Department of Anatomy and Neurobiology. Among this astute group of neighbors was the brilliant embryologist, Viktor Hamburger, who with Rita Levi-Montalcini, had discovered NGF and founded the field of nerve growth factors.

With that as my backdrop, I fittingly began my postdoctoral studies in the Bunge laboratory by interrogating the age-old question of nature versus nurture and the role of each in the development of the catecholamine neuron. More specifically, we sought to determine how a neuron came to express a catecholamine phenotype during development and whether that fate could be altered by its environment, a question the answer for which ultimately led to the discovery of another important growth factor. The first installment in that work, entitled "Dual expression of neurotransmitter synthesis in cultured autonomic neurons," was published in the inaugural issue of The Journal of Neuroscience (Iacovitti et al., 1981).

\section{Catecholamine phenotypic plasticity}

At its core, this study aimed to resolve a brewing controversy in the literature: whether neurons could be induced to express more than one neurotransmitter and whether the acquisition of the new transmitter type occurred at the expense of the inherited 
phenotype. Focusing solely on neurons was new territory for the Bunge laboratory, renowned for its pioneering work on Schwann cells and myelination. Therefore, Dick turned to our downstairs neighbor in the Pharmacology Department, Gene Johnson, to help guide my day-to-day biochemical analyses of these neurons. Gene, celebrated for his work on neurotrophic factors, generously allowed me to move in and take over a whole section of his laboratory with my TH enzyme assays and Northern blots. He welcomed me, as did everyone in his laboratory, with forbearance, daily good humor, and a great deal of scientific wisdom.

We used as our experimental model sympathetic adrenergic neurons of the superior cervical ganglion (SCG) which were grown in culture under conditions conducive to the induction of a cholinergic phenotype. As the title of our article suggests, we found that virtually all SCG neurons were capable of dual neurotransmitter production and thus the potential for dual function (Fig. 1) (Iacovitti et al., 1981, 1982). Simultaneously, our colleagues at Harvard (Drs. Furshpan, Potter, Patterson, and Landis) explored similar questions in adrenergic and cholinergic sympathetic neurons in vitro and in vivo (Landis, 1980; Potter et al., 1981). Although there was some back and forth between the Harvard and Washington University groups (much of which played itself out in the pages of The Journal of Neuroscience and at Society of Neuroscience meetings), ultimately, both groups came to agree that the adrenergic phenotype was sustained longterm as evidenced by the continued expression of enzymatically active $\mathrm{TH}$ and catecholamine uptake in sympathetic neurons despite the acquisition of new cholinergic properties (Higgins et al., 1981; Iacovitti et al., 1981, 1982; Johnson et al., 1981; Potter et al., 1981; Landis and Keefe, 1983; Wolinsky and Patterson, 1983). The phenotypic plasticity displayed by these postmitotic autonomic neurons was paradigm shifting at the time, given the prevailing belief in Dale's Principle of "one neuron, one transmitter" (Dale, 1935).

Having completed my postdoctoral fellowship, I moved back to Cornell University Medical College in New York as an Assistant Professor in the Neurology Department. There I had the enormous good fortune to collaborate with Gladys Teitelman, who became a lifelong friend and a pivotal mentor during my early career years. Capitalizing on her rich background as a developmental biologist, together Gladys and I expanded the study of phenotypic plasticity to her favorite developmental model, the chick embryo. We found that, like adrenergic sympathetic neurons, cholinergic parasympathetic neurons in the chicken ciliary ganglion could similarly be induced by environmental cues to express a dual transmitter phenotype (Iacovitti et al., 1985, 1987; Teitelman et al., 1985).

\section{Catecholamine differentiation and the muscle-derived differentiation factor (MDF) story}

In 1989, with a husband and two small daughters in tow, I returned to my hometown of Philadelphia to open a laboratory in the newly formed Neuroscience Institute at Hahnemann University. There, I set my horizons northward on neurons of the brain. Up to that point, the field had convincingly shown that PNS neurons were phenotypically plastic, but no one had yet to ask whether neurons of the more static brain shared this remarkable ability. Using cultures of primary mouse cortical and striatal neurons, we found that "something" present in muscle extract, we later coined MDF, was capable of promoting the expression of catecholamine traits (TH mRNA and TH protein) in noncatecholamine neurons of the brain (Iacovitti et al., 1989; Iacovitti, 1991). We concluded that phenotypic plasticity

\section{EXPERIMENT I}
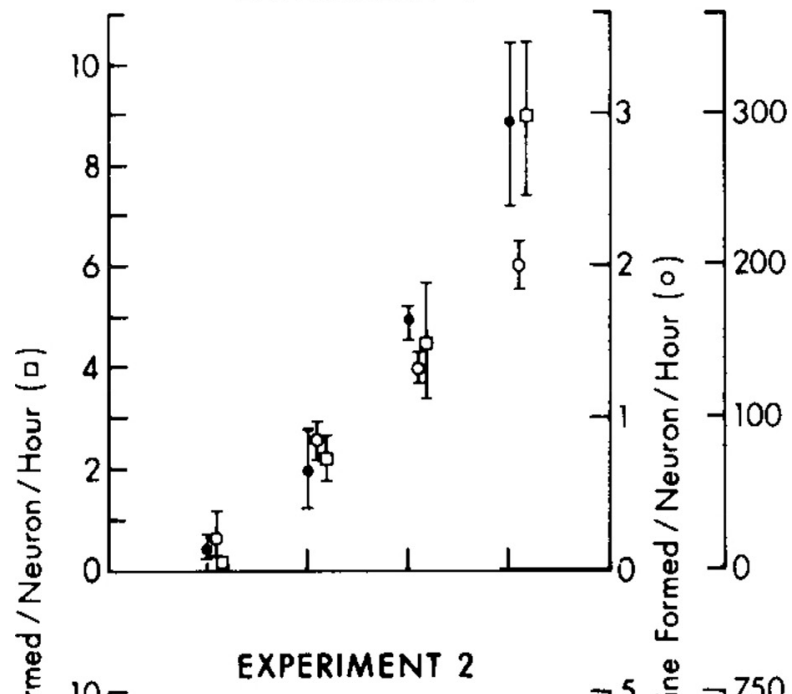

2

EXPERIMENT 2

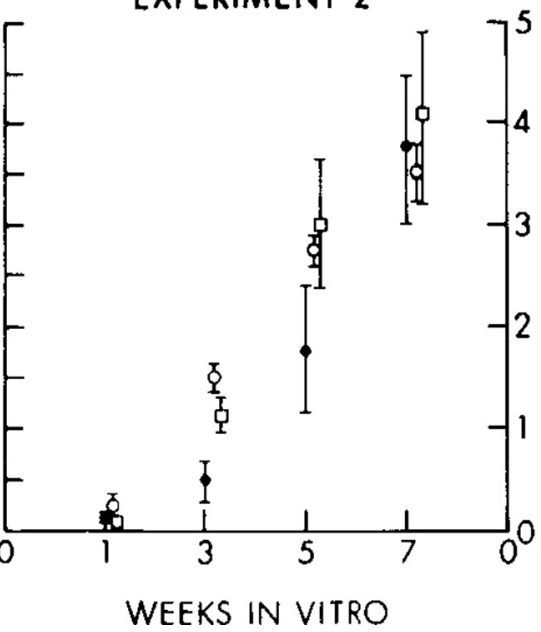

Figure 1. Time course of changes in TH, dopamine- $\beta$-hydroxylase (DBH), and ChAT activities in cultures of dissociated perinatal rat SCG. Each experiment represents cultures derived from one group of fetuses and maintained in an identical manner. Each point represents the mean + SEM of five preparations. In Experiments 1 and 2, ChAT activity (0) increased in an identical manner, reaching levels of $\sim 9 \mathrm{pmol}$ of acetylcholine (Ach)/neuron/hr by 7 weeks in culture. While the magnitude of the increases in the activities of TH (0) and DBH (0) remained the same for both experiments, the maximal levels of activity reached at 7 weeks in vitro differed in Experiments 1 and 2. The activity of all three enzymes in both experiments differed significantly between 3 and 7 weeks in vitro. In Experiment 1: for TH, $p<0.05$; for DBH, $p<0.001$; for ChAT, $p<0.05$. In Experiment 2: for TH, $p<0.05$; for DBH, $p<0.01$; and for CAT, $p<0.001$. Reprinted with permission from lacovitti et al. (1981).

represented a more encompassing principle, such that neurons of the CNS, just as those in periphery, could undergo phenotypic interconversion in response to biologically active molecules in their environment.

After several years of protein purification by a gifted biochemist in my laboratory, Xinyu Du, and wonderful collaborators at Amgen, we showed in a series of five Journal of Neuroscience papers, that MDF activity resulted not from one substance but from the synergy of fibroblast growth factor 1 and small activating molecules of the PKA/PKC pathways (Iacovitti et al., 1989; Iacovitti, 1991; Du et al., 1994; Du and Iacovitti, 1995; Guo et al., 1998). I can remember to this day the disappointment I felt when MDF turned out not to be a novel protein that the laboratory could run with for years. It was an important reminder that science is the search for truth, no matter how inconvenient that truth is for one's personal career goals. We 
went on to show that, during this transdifferentiation, signals were transmitted via MAP kinase to the TH-AP1 site to increase activators and reduce repressors, helping to shift the balance in favor of TH gene expression at this and possibly other important regulatory sites on the gene (Guo et al., 1998). Somewhat surprisingly, we subsequently found that infusion of these factors into the striatum of unilaterally 6-OHDA-lesioned rats caused a significant and long-lasting reduction in motor deficits, suggesting that they might be important in regulating the production of dopamine in the injured brain and, thus, be of use in the treatment of Parkinson's disease (PD) (B. K. Jin and Iacovitti, 1995).

\section{The revolution of stem cells}

Nearly a decade later, I moved across town to a new academic home at Thomas Jefferson University Medical School where I remain today as a Professor of Neuroscience. Little did I understand then that a scientific revolution was on the horizon that would reshape the rest of my days in science. In 1998, Jamie Thomson at the University of Wisconsin published his trailblazing study in Science demonstrating that it was possible to create a line of human embryonic stem cells (hESCs) from the human blastocyst (Thomson, 1998). By that point, I was quite comfortable in the world of developmental neuroscience, but I knew almost nothing about stem cells. So intrigued was I at the prospect of using hESCs to study and potentially treat neurodegenerative disease, however, that I willingly jumped in head first to the brave new world of stem cells. Together with my young technician Angela Donaldson, we began to fathom our way around these fascinating but highly challenging cells, learning much to our chagrin how easily they spontaneously differentiated in the dish, regardless of the experiments we had planned for them. Like so many others, we were anxious to direct the differentiation of hES cells into dopamine neurons (Perrier et al., 2004; Zeng et al., 2004; Park et al., 2005; Iacovitti et al., 2007; Friling et al., 2009; Cai et al., 2010; Cooper et al., 2010; Lee et al., 2010; Morizane et al., 2010); the cell lost from the midbrain substantia nigra (SN) in PD (Hirsch et al., 1988). Theoretically, dopaminedifferentiated stem cells could be used to replace those in the diseased SN, the majority of which have degenerated by the time PD patients present with their first motor symptoms. Fueling the PD field's enthusiasm over the promise of stem cells were earlier transplant studies showing that grafts of human fetal midbrain tissue had an ameliorative effect on PD patients (Freed et al., 2001; Olanow et al., 2003). However, the harvest of fetal tissue proved incredibly variable, finite in amount and totally impractical in the clinic, sometimes producing unwelcome outcomes (Folkerth and Durso, 1996; Freed et al., 2001; Hagell et al., 2002; Ma et al., 2002; Olanow et al., 2003). Therefore, stem cells, representing an unlimited and more uniform source of transplantable tissue, seemed the ideal answer to our troubles.

Society, however, viewed this brave new world with more trepidation; and on August 9, 2001, President George W. Bush imposed a ban on the use of National Institutes of Health funds for the study of all new hES cell lines. Fortunately, work was allowed to proceed with Thomson's original H9 hES line, which remains to this day, the gold standard in the field. Nonetheless, the ban slowed progress, and, importantly, discouraged many young scientists from entering the nascent field of stem cells.

\section{Directing induced pluripotent stem cells (iPSCs) into midbrain dopamine neurons}

With the ban in place, necessity became the mother of invention. In just 5 short years, the scientific world found its way around the thorny ethical issues surrounding the use of human embryonic tissue with the revolutionary discovery of induced pluripotency. Thus, in 2006, Takahashi and Yamanaka published their landmark study on mouse iPSCs, earning Yamanaka the Nobel prize 6 years later. Remarkably, both the Thomson and Yamanaka laboratories established human iPSC lines just 1 year later (Takahashi et al., 2007; Yu et al., 2007).

Through the years of the stem cell ban, my laboratory continued to work developing a protocol to differentiate a dopamine phenotype in hES cells (Yang et al., 2003, 2004; Iacovitti et al., 2007) while pressing to understand how that regulation occurred at the level of the TH gene in those cells (Romano et al., 2005, 2007; H. Jin et al., 2006). Once again, good luck played an important role in what happened next. At about this time, Jingli Cai arrived in my laboratory as a new postdoctoral fellow having completed her training in the premier stem cell laboratory at the National Institutes of Health under the tutelage of Mahendra Rao. With Jingli's capable hands, we were well positioned to move from predominantly hES cells to human iPSCs in the next critical chapter of our work.

Cai's early studies were pivotal in showing the critical role played by the fate gene Lmxla in the differentiation of hES cells and iPSCs into midbrain dopamine neurons in culture (Cai et al., 2009, 2010). Moreover, Jingli showed that stem-cell-derived midbrain dopamine progenitors transplanted into 6-OHDAlesioned PD rats survived long-term and expressed many, though not all, of the traits of a full authentic midbrain dopamine phenotype. Like others in the field at that time (Arenas, 2002; Kim et al., 2002; Hedlund et al., 2008; Lee et al., 2010; Kriks et al., 2011), we also found a multitude of other cell types present in midbrain dopamine-differentiated cultures and grafts (Cai et al., 2010). Together, these issues caused us to reexamine more closely the blueprint for midbrain dopamine differentiation in vivo. We found that a critical balance was necessary between reciprocally regulated $\mathrm{Wnt}$ and $\mathrm{SHH}$ pathways for the induction of a bona fide midbrain dopamine phenotype (Cai et al., 2013). Thus, Wnt signals, important in anterior-posterior axis development and the expression of Lmxla in midbrain dopamine progenitors, along with $\mathrm{SHH}$ signals, important in ventral to dorsal axis development and the induction of another key midbrain dopamine fate gene, Foxa2, must be present at the appropriate concentrations and times in culture, mimicking the spaciotemporal cues driving the development of midbrain dopamine neurons in the brain (Joksimovic et al., 2009a,b; Tang et al., 2010; Joksimovic and Awatramani, 2014; Mesman et al., 2014).

However, it was only after initiating an important collaboration with colleagues at Jefferson, Drs. Alex Mazo and Svetlana Petruk, that we came to appreciate how important the very earliest stages of differentiation were to the outcome of this process in stem cells. Using a clever technique developed by the Mazo laboratory called the chromatin assembly assay for single-cell gene-specific analysis (Petruk et al., 2016), we showed that there was a critical "window of opportunity" for the recruitment of lineage-specifying transcription factors, such as Lmxla and Foxa2 to DNA. This window surprisingly occurred during the first hours after induction of midbrain dopamine differentiation in culture (Fig. 2) (Petruk et al., 2017).

Normally, in activating new transcriptional programs during differentiation, transcription factors are recruited to repressed genes in euchromatin. However, this recruitment process is impeded by the repressive histone mark H3K27me3 on condensed chromatin. Our study revealed that, during the first hours of midbrain dopamine differentiation in hES cells and iPSCs, the 
accrual of the H3K27me3 was delayed on post-replicative DNA, indicative of a decondensed chromatin structure. This delay provided a window during which Lmxla and Foxa2 and other critical transcription factors could bind DNA to drive forward the midbrain dopamine differentiation process (Fig. 3).

\section{iPSCs in disease modeling}

As the field amassed greater confidence in the fidelity of the cell types being differentiated from stem cells, there was a major shift toward disease modeling in iPSC cultures. The importance of this newfound ability to differentiate iPSCs carrying the patient genome into cell types relevant to their disease cannot be overstated. It made possible the study of pathogenic mechanisms in the dish, how gene mutations are influenced by their environment in the disease process, and provided a platform to rapidly test potential new therapeutics. The burgeoning literature reflected the stem cell revolution that was underway (for review, see Mattis and Svendsen, 2011; Xie and Tang, 2016).

For my laboratory, this launched a highly collaborative period examining PD using all the tools that had been developed in the laboratory over the years, including iPSCs carrying PD gene mutations (LRRK2, $\alpha$-synuclein triplication) as well as our TH-GFP reporter mouse (Kessler et al., 2003) and rat (Iacovitti et al., 2014) models. Thus, with colleagues at Vanderbilt, we found that TH-GFP-tagged midbrain dopamine neurons derived from mouse stem cells were morphologically and functionally indistinguishable from fetal midbrain dopamine neurons (Gu et al., 2015). In other studies with K. S. Kim (Harvard Medical School), we examined the role of the leucine-rich repeat kinase 2 (LRRK2) gene mutation in normal and PD brain and found that the dysfunction in SN dopamine neurons caused by mutant LRRK2 may be directly responsible for the selective degeneration of those cells (Han et al., 2008). In a collaboration with colleagues at Hopkins, a transgenic mouse line was generated wherein $11 \mathrm{~kb}$ of the human $\mathrm{TH}$ promoter was used to drive G2019S LRRK2 expression. Importantly, these mice showed an age- and kinase-dependent degeneration of brain catecholamine neurons with consequent motor deficits (Xiong et al., 2018). Using PD iPSCs carrying the G2019S mutation, Cai went on to show that the LRRK2 kinase inhibitor CZC54252, a potential therapeutic, could rescue midbrain dopamine neurons from their deadly fate after challenge by neurotoxins (Cai, unpublished data; Fig. 4).

Our work on iPSCs led to the establishment of the Jefferson Stem Cell and Regenerative Neuroscience Center in 2016. This greatly expanded our reach beyond $\mathrm{PD}$, allowing us to provide stem cells to the wider Jefferson community for the study of an array of neurodegenerative diseases. Thus, in collaborative experiments where iPSCs from C9orf72-ALS patients were differentiated into spinal motor neurons and used to study ALS pathogenic mechanisms, the Trotti/Passinelli laboratory showed evidence of cell-to-cell spread of potentially disease-causing dipeptide repeat proteins (Westergard et al., 2016). More recently, in a collaboration with Jefferson colleagues studying Charcot-Marie-Tooth disease, we developed a new gene editing approach to correct the disease mutation in iPSCs generated from Charcot-Marie-Tooth patients (Cai et al., 2021).

\section{Going forward}

One of our current goals is the creation of reporter iPS lines to help track changes in live differentiated IPSCs which would also enable the segregation of midbrain dopamine progenitors and/or midbrain dopamine neurons for studies in vitro and in vivo. Despite many years of striving to better direct the midbrain dopamine differentiation process, this remains an important objective for the stem cell field in the face of ongoing cell heterogeneity. In vitro, this heterogeneity creates an environment which is not physiologically relevant, confounding disease modeling results. In grafts, the presence of heterogeneous cell types (including potentially excitotoxic glutamatergic neurons) poses a major stumbling block in moving stem cells to the clinic. Thus, we are currently working on the generation of Lmx1a, En1, Pitx3, and TH reporter iPSC lines using new advances in gene editing methodologies (Cai et al., 2021). These reporter lines will hopefully address the vexing issue of cell heterogeneity by allowing us to FACS purify midbrain dopamine progenitors and midbrain dopamine neurons for PD modeling in culture. In addition, these purified genetically engineered cells offer the opportunity to identify novel midbrain dopamine-specific cell surface markers, making it possible in the future to FACS sort nonengineered midbrain dopamine neurons for transplantation of replacement cells in PD patients. 
A

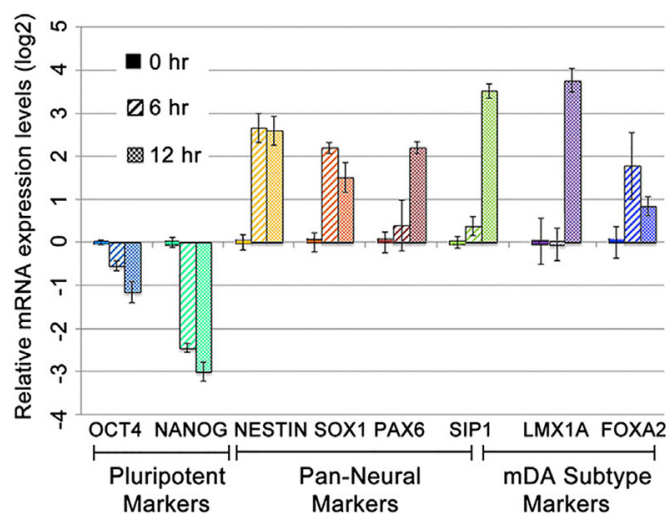

B

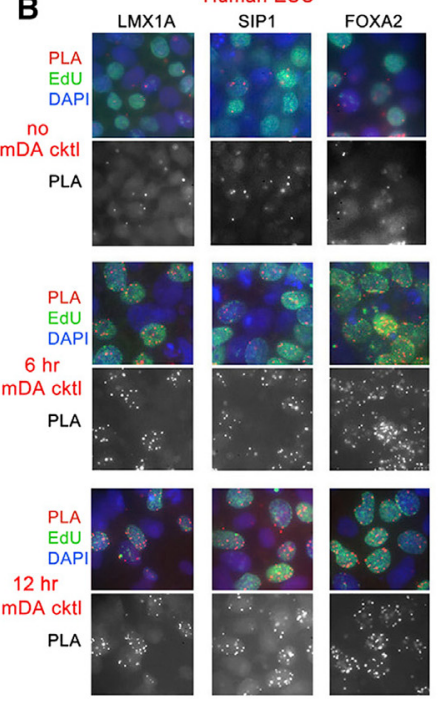

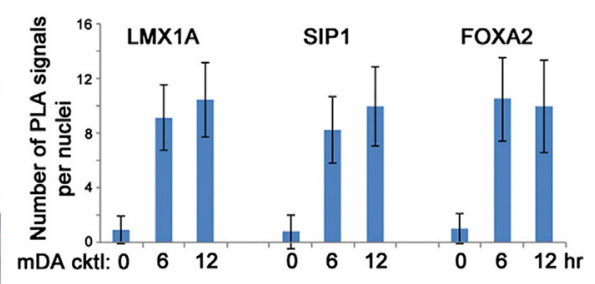

Figure 3. Induction of expression and association with DNA of lineage-specific transcription factors during midbrain dopamine differentiation of hESCs. $A$, qRT-PCR gene expression analysis of undifferentiated ( $0 \mathrm{~h}$, control) hESCs and hESCs induced to the midbrain dopamine lineage for 6 and $12 \mathrm{~h}$. B. Undifferentiated hESCs (top) and hESCs induced to the midbrain dopamine lineage for 6 or $12 \mathrm{~h}$ (bottom) were labeled with EdU for $15 \mathrm{~min}$ and then chased for $15 \mathrm{~min}$. Chromatin assembly assay (CAA) is a method based on the proximity ligation assay (PLA) that allows examination of proteins associated with nascent DNA following replication in single cells. CAA was performed for LMX1A, FOXA2, and SIP1 followed by immunostaining for biotin (green). PLA only is shown in black and white. Quantification of the results of three independent CAA experiments is also shown (right): $x$ axis, hours in midbrain dopamine differentiation cocktail; $y$ axis, number of PLA signals per nucleus. Reprinted with permission from Petruk et al. (2017).
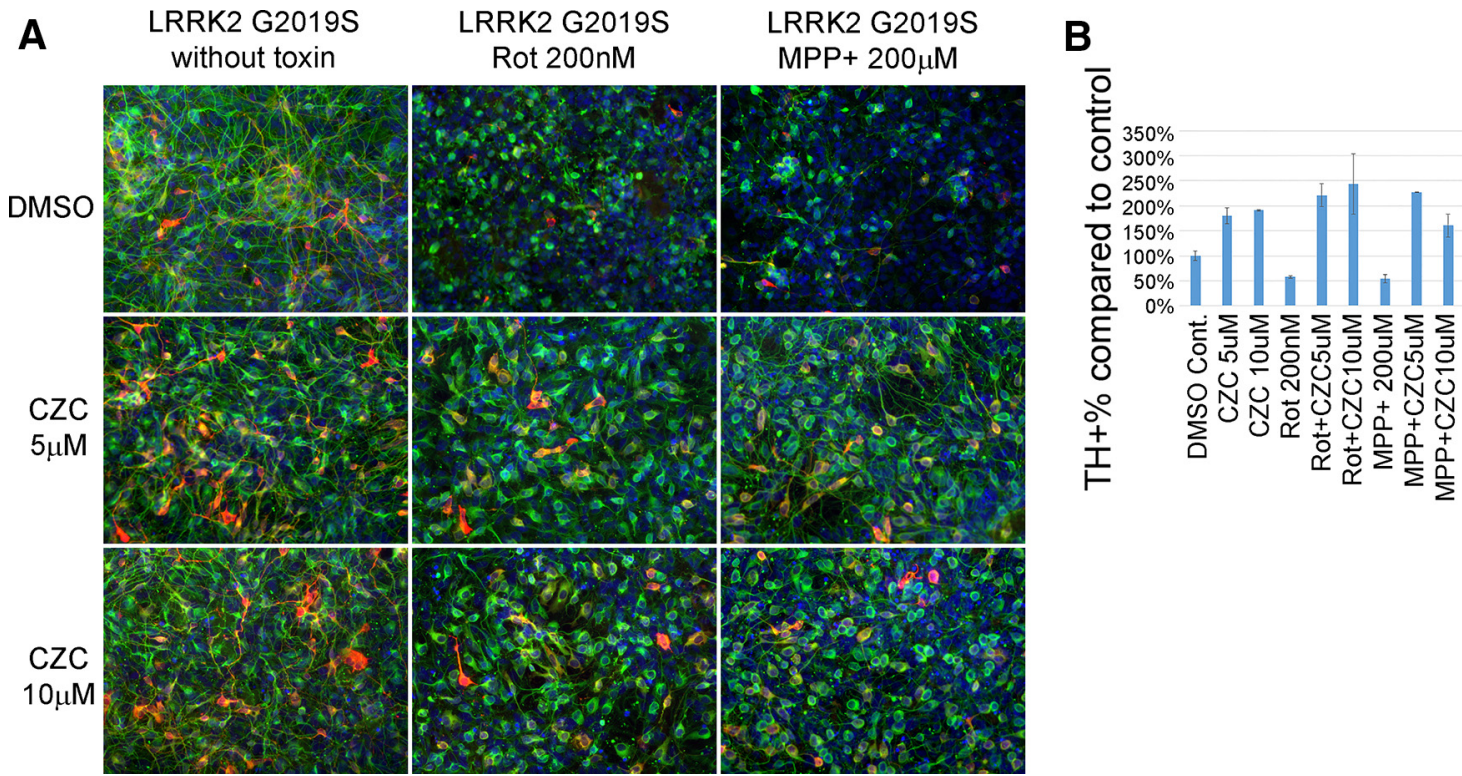

Figure 4. LRRK2 kinase inhibitor CZC54252 rescues LRRK2 iPS-derived dopamine neurons from neurotoxin-induced cell death. $\boldsymbol{A}$, LRRK2 G2019S iPS-derived dopamine neurons were treated with $5 \mu \mathrm{m}, 10 \mu \mathrm{m}$ LRRK2 kinase inhibitor (ZC54252 (bottom two rows), while DMSO was added to control wells (top row). On the next day, fresh medium containing neurotoxins, $200 \mathrm{~nm}$ rotenone (Rot, middle column) or $200 \mu \mathrm{m}$ 1-methyl-4-phenylpyridinium (MPP ${ }^{+}$) (right column), were added together with the same doses of (ZC54252. Forty-eight hours later, all wells fixed and stained with antibodies to TH (red) and blll tubulin (green) and counterstained with DAPI nuclear stain (blue). $\boldsymbol{B}$, In the absence of CZC5252, rotenone or MPP ${ }^{+}$treatment caused the death of a large percentage of dopamine neurons $\left(\mathrm{TH}^{+}\right)$. Both dosages of $\mathrm{CZC} 5252$ significantly increased the survival of $\mathrm{TH}^{+}$cells both in control conditions (reason still unknown) and after treatment with rotenone and $\mathrm{MPP}^{+}$.

Finally, the laboratory is once again captivated by another important growth factor, GDF15. Studies by Eric Kostuk, then a graduate student in the laboratory, showed that subregional differences in midbrain astrocytes and their expression of GDF15 may underlie the selective degeneration of SN midbrain dopamine neurons and protection of VTA dopamine neurons in models of PD. Because the receptor for GDF15, GFRAL, is present on vulnerable SN dopamine neurons, it may represent an important therapeutic target in the future (Kostuk et al., 2019).
In conclusion, in looking back on my journey from there to here, it is truly surprising to me how linear our progress now appears. I assure you it did not seem so at the time. There were of course many off ramps into new areas of science not discussed here. Still, it is undeniably clear that my original passion for catecholamine differentiation and the principles that govern that process remained an important undercurrent throughout my career. In the retelling, I am also struck by the hefty dose of good luck that helped at each step along the way, from landing in 
laboratories with extraordinary mentors purely by happenstance to serendipitous conversations in hallways that led to important collaborations. Mostly, however, I recognize that whatever success the laboratory has enjoyed, is owed entirely to the exceptional students and postdocs throughout the years. These young dedicated scientists and their passions in science promise a bright future.

\section{References}

Arenas E (2002) Stem cells in the treatment of Parkinson's disease. Brain Res Bull 57:795-808.

Cai J, Donaldson A, Yang M, German MS, Enikolopov G, Iacovitti L (2009) The role of Lmxla in the differentiation of human embryonic stem cells into midbrain dopamine neurons in culture and after transplantation into a Parkinson's disease model. Stem Cells 27:220-229.

Cai J, Yang M, Poremsky E, Kidd S, Schneider JS, Iacovitti L (2010) Dopaminergic neurons derived from human induced pluripotent stem cells survive and integrate into 6-OHDA-lesioned rats. Stem Cells Dev 19:1017-1023.

Cai J, Schleidt S, Pelta-Heller J, Hutchings D, Cannarsa G, Iacovitti L (2013) BMP and TGF- $\beta$ pathway mediators are critical upstream regulators of Wnt signaling during midbrain dopamine differentiation in human pluripotent stem cells. Dev Biol 376:62-73.

Cai J, Kropf E, Hou YM, Iacovitti L (2021) A stress-free strategy to correct point mutations in patient iPS cells. Stem Cell Res 53:102332.

Cooper O, Hargus G, Deleidi M, Blak A, Osborn T, Marlow E, Lee K, Levy A, Perez-Torres E, Yow A, Isacson O (2010) Differentiation of human ES and Parkinson's disease iPS cells into ventral midbrain dopaminergic neurons requires a high activity form of $\mathrm{SHH}, \mathrm{FGF}$ a and specific regionalization by retinoic acid. Mol Cell Neurosci 45:258-266.

Dale H (1935) Pharmacology and nerve-endings (Walter Ernest Dixon Memorial Lecture): (Section of Therapeutics and Pharmacology). Proc R Soc Med 28:319-332.

Du X, Iacovitti L (1995) Synergy between growth factors and transmitters required for catecholamine differentiation in brain neurons. J Neurosci 15:5420-5427.

Du X, Stull ND, Iacovitti L (1994) Novel expression of the tyrosine hydroxylase gene requires both acidic fibroblast growth factor and an activator. J Neurosci 14:7688-7694.

Falck B (1962) Observations on the possibilities of the cellular localization of monoamines by a fluorescence method. ACT A Physiol A Scand A 56:125.

Folkerth RD, Durso R (1996) Survival and proliferation of nonneural tissues, with obstruction of cerebral ventricles, in a parkinsonian patient treated with fetal allografts. Neurology 46:1219-1225.

Freed CR, Greene PE, Breeze RE, Tsai WY, DuMouchel W, Kao R, Dillon S, Winfield H, Culver S, Trojanowski JQ, Eidelberg D, Fahn S (2001) Transplantation of embryonic dopamine neurons for severe Parkinson's disease. N Engl J Med 344:710-719.

Friling S, Andersson E, Thompson LH, Jönsson ME, Hebsgaard JB, Nanou E, Alekseenko Z, Marklund U, Kjellander S, Volakakis N, Hovatta O, El Manira A, Björklund A, Perlmann T, Ericson J (2009) Efficient production of mesencephalic dopamine neurons by Lmxla expression in embryonic stem cells. Proc Natl Acad Sci USA 106:7613-7618.

Gu H, Lazarenko RM, Koktysh D, Iacovitti L, Zhang Q (2015) A stem cellderived platform for studying single synaptic vesicles in dopaminergic synapses. Stem Cells Transl Med 4:887-893.

Guo Z, Du X, Iacovitti L (1998) Regulation of tyrosine hydroxylase gene expression during transdifferentiation of striatal neurons: changes in transcription factors binding the AP-1 site. J Neurosci 18:8163-8174.

Hagell P, Piccini P, Björklund A, Brundin P, Rehncrona S, Widner H, Crabb L, Pavese N, Oertel WH, Quinn N, Brooks DJ, Lindvall O (2002) Dyskinesias following neural transplantation in Parkinson's disease. Nat Neurosci 5:627-628.

Han BS, Iacovitti L, Katano T, Hattori N, Seol W, Kim KS (2008) Expression of the LRRK2 gene in the midbrain dopaminergic neurons of the substantia nigra. Neurosci Lett 442:190-194

Hedlund E, Pruszak J, Lardaro T, Ludwig W, Viñuela A, Kim KS, Isacson O (2008) Embryonic stem cell-derived Pitx3-enhanced green fluorescent protein midbrain dopamine neurons survive enrichment by fluorescence-activated cell sorting and function in an animal model of Parkinson's disease. Stem Cells 26:1526-1536.

Higgins D, Iacovitti L, Joh TH, Burton H (1981) The immunocytochemical localization of tyrosine hydroxylase within rat sympathetic neurons that release acetylcholine in culture. J Neurosci 1:126-131.

Hirsch E, Graybiel AM, Agid YA (1988) Melanized dopaminergic neurons are differentially susceptible to degeneration in Parkinson's disease. Nature 334:345-348.

Iacovitti L (1991) Effects of a novel differentiation factor on the development of catecholamine traits in noncatecholamine neurons from various regions of the rat brain: studies in tissue culture. J Neurosci 11:24032409.

Iacovitti L, Joh TH, Park DH, Bunge RP (1981) Dual expression of neurotransmitter synthesis in cultured autonomic neurons. J Neurosci 1:685690.

Iacovitti L, Johnson MI, Joh TH, Bunge RP (1982) Biochemical and morphological characterization of sympathetic neurons grown in a chemicallydefined medium. Neuroscience 7:2225-2239.

Iacovitti L, Joh TH, Albert VR, Park DH, Reis DJ, Teitelman G (1985) Partial expression of catecholaminergic traits in cholinergic chick ciliary ganglia: studies in vivo and in vitro. Dev Biol 110:402-412.

Iacovitti L, Teitelman G, Joh TH, Reis DJ (1987) Chick eye extract promotes expression of a cholinergic enzyme in sympathetic ganglia in culture. Dev Brain Res 33:59-65.

Iacovitti L, Evinger MJ, Joh TH, Reis DJ (1989) A muscle-derived factor(s) induces expression of a catecholamine phenotype in neurons of cultured rat cerebral cortex. J Neurosci 9:3529-3537.

Iacovitti L, Donaldson AE, Marshall CE, Suon S, Yang M (2007) A protocol for the differentiation of human embryonic stem cells into dopaminergic neurons using only chemically defined human additives: studies in vitro and in vivo. Brain Res 1127:19-25.

Iacovitti L, Wei X, Cai J, Kostuk EW, Lin R, Gorodinsky A, Roman P, Kusek G, Das SS, Dufour A, Martinez TN, Dave KD (2014) The hTH-GFP reporter rat model for the study of Parkinson's disease. PLoS One 9: e113151.

Jin BK, Iacovitti L (1995) Dopamine differentiation factors produce partial motor recovery in 6- hydroxydopamine lesioned rats. Neurobiol Dis 2:112.

Jin H, Romano G, Marshall C, Donaldson AE, Suon S, Iacovitti L (2006) Tyrosine hydroxylase gene regulation in human neuronal progenitor cells does not depend on Nurr1 as in the murine and rat systems. J Cell Physiol 207:49-57.

Johnson MI, Iacovitti L, Higgins D, Bunge RP, Burton H (1981) Growth and development of sympathetic neurons in tissue culture. In: Ciba Found Symp, pp 108-122. New York: Wiley.

Joksimovic M, Awatramani R (2014) Wnt/ $\beta$-catenin signaling in midbrain dopaminergic neuron specification and neurogenesis. J Mol Cell Biol 6:27-33.

Joksimovic M, Anderegg A, Roy A, Campochiaro L, Yun B, Kittappa R, McKay R, Awatramani R (2009a) Spatiotemporally separable Shh domains in the midbrain define distinct dopaminergic progenitor pools. Proc Natl Acad Sci USA 106:19185-19190.

Joksimovic M, Yun BA, Kittappa R, Anderegg AM, Chang WW, Taketo MM, McKay RD, Awatramani RB (2009b) Wnt antagonism of Shh facilitates midbrain floor plate neurogenesis. Nat Neurosci 12:125-131.

Kessler MA, Yang M, Gollomp KL, Jin H, Iacovitti L (2003) The human tyrosine hydroxylase gene promoter. Brain Res Mol Brain Res 112:8-23.

Kim JH, Auerbach JM, Rodríguez-Gómez JA, Velasco I, Gavin D, Lumelsky N, Lee SH, Nguyen J, Sánchez-Pernaute R, Bankiewicz K, McKay R (2002) Dopamine neurons derived from embryonic stem cells function in an animal model of Parkinson's disease. Nature 418:50-56.

Kostuk EW, Cai J, Iacovitti L (2019) Subregional differences in astrocytes underlie selective neurodegeneration or protection in Parkinson's disease models in culture. Glia 67:1542-1557.

Kriks S, Shim JW, Piao J, Ganat YM, Wakeman DR, Xie Z, Carrillo-Reid L, Auyeung G, Antonacci C, Buch A, Yang L, Beal MF, Surmeier DJ, Kordower JH, Tabar V, Studer L (2011) Dopamine neurons derived from human ES cells efficiently engraft in animal models of Parkinson's disease. Nature 480:547-551.

Landis SC (1980) Developmental changes in the neurotransmitter properties of dissociated sympathetic neurons: a cytochemical study of the effects of medium. Dev Biol 77:349-361. 
Landis SC, Keefe D (1983) Evidence for neurotransmitter plasticity in vivo: developmental changes in properties of cholinergic sympathetic neurons. Dev Biol 98:349-372.

Le Douarin NM (1980) The ontogeny of the neural crest in avian embryo chimaeras. Nature 286:663-669.

Lee HS, Bae EJ, Yi SH, Shim JW, Jo AY, Kang JS, Yoon EH, Rhee YH, Park $\mathrm{CH}$, Koh HC, Kim HJ, Choi HS, Han JW, Lee YS, Kim J, Li JY, Brundin P, Lee SH (2010) Foxa2 and Nurr1 synergistically yield A9 nigral dopamine neurons exhibiting improved differentiation, function, and cell survival. Stem Cells 28:501-512.

Ma Y, Feigin A, Dhawan V, Fukuda M, Shi Q, Greene P, Breeze R, Fahn S, Freed C, Eidelberg D (2002) Dyskinesia after fetal cell transplantation for parkinsonism: a PET study. Ann Neurol 52:628-634.

Mattis VB, Svendsen CN (2011) Induced pluripotent stem cells: a new revolution for clinical neurology? Lancet Neurol 10:383-394.

Mesman S, Von Oerthel L, Smidt MP (2014) Mesodiencephalic dopaminergic neuronal differentiation does not involve GLI2A-mediated SHH-signaling and is under the direct influence of canonical WNT signaling. PLoS One 9:e97926.

Morizane A, Darsalia V, Guloglu MO, Hjalt T, Carta M, Li JY, Brundin P (2010) A simple method for large-scale generation of dopamine neurons from human embryonic stem cells. J Neurosci Res 88:34673478.

Olanow CW, Goetz CG, Kordower JH, Stoessl AJ, Sossi V, Brin MF, Shannon KM, Nauert GM, Perl DP, Godbold J, Freeman TB (2003) A double-blind controlled trial of bilateral fetal nigral transplantation in Parkinson's disease. Ann Neurol 54:403-414.

Park CH, Minn YK, Lee JY, Choi DH, Chang MY, Shim JW, Ko JY, Koh HC, Kang MJ, Kang JS, Rhie DJ, Lee YS, Son H, Moon SY, Kim KS, Lee SH (2005) In vitro and in vivo analyses of human embryonic stem cellderived dopamine neurons. J Neurochem 92:1265-1276.

Perrier AL, Tabar V, Barberi T, Rubio ME, Bruses J, Topf N, Harrison NL, Studer L (2004) Derivation of midbrain dopamine neurons from human embryonic stem cells. Proc Natl Acad Sci USA 101:1254312548 .

Petruk S, Fenstermaker TK, Black KL, Brock HW, Mazo A (2016) Detection of RNA-DNA association by a proximity ligation-based method. Sci Rep 19:295-306.

Petruk S, Cai J, Sussman R, Sun G, Kovermann SK, Mariani SA, Calabretta B, McMahon SB, Brock HW, Iacovitti L, Mazo A (2017) Delayed accumulation of $\mathrm{H} 3 \mathrm{~K} 27 \mathrm{me} 3$ on nascent DNA is essential for recruitment of transcription factors at early stages of stem cell differentiation. Mol Cell 66:247-257.e5.

Potter DD, Landis SC, Furshpan EJ (1981) Adrenergic-cholinergic dual function in cultured sympathetic neurons of the rat. In: Ciba Found Symp, pp 123-150. New York: Wiley.
Romano G, Macaluso M, Lucchetti C, Iacovitti L (2007) Transcription and epigenetic profile of the promoter, first exon and first intron of the human tyrosine hydroxylase gene. J Cell Physiol 211:431-438.

Romano G, Suon S, Jin H, Donaldson AE, Iacovitti L (2005) Characterization of five evolutionary conserved regions of the human tyrosine hydroxylase (TH) promoter: implications for the engineering of a human TH minimal promoter assembled in a self-inactivating lentiviral vector system. J Cell Physiol 204:666-677.

Takahashi K, Tanabe K, Ohnuki M, Narita M, Ichisaka T, Tomoda K, Yamanaka S (2007) Induction of pluripotent stem cells from adult human fibroblasts by defined factors. Cell 131:861-872.

Tang M, Villaescusa JC, Luo SX, Guitarte C, Lei S, Miyamoto Y, Taketo MM, Arenas E, Huang EJ (2010) Interactions of Wnt/beta-catenin signaling and sonic hedgehog regulate the neurogenesis of ventral midbrain dopamine neurons. J Neurosci 30:9280-9291.

Teitelman G, Joh TH, Grayson L, Park DH, Reis DJ, Iacovitti L, (1985) Cholinergic neurons of the chick ciliary ganglia express adrenergic traits in vivo and in vitro. J Neurosci 5:29-39.

Thomson JA (1998) Embryonic stem cell lines derived from human blastocysts. Science 282:1145-1147.

Westergard T, Jensen BK, Wen X, Cai J, Kropf E, Iacovitti L, Pasinelli P, Trotti D (2016) Cell-to-cell transmission of dipeptide repeat proteins linked to C9orf72-ALS/FTD. Cell Rep 17:645-652.

Wolinsky E, Patterson PH (1983) Tyrosine hydroxylase activity decreases with induction of cholinergic properties in cultured sympathetic neurons. J Neurosci 3:1495-1500.

Xie N, Tang B (2016) The application of human iPSCs in neurological diseases: from bench to bedside. Stem Cells Int 2016: 1-10.

Xiong Y, Neifert S, Karuppagounder SS, Liu Q, Stankowski JN, Lee BD, Ko HS, Lee Y, Grima JC, Mao X, Jiang H, Kang SU, Swing DA, Iacovitti L, Tessarollo L, Dawson TM, Dawson VL (2018) Robust kinase- and age-dependent dopaminergic and norepinephrine neurodegeneration in LRRK2 G2019S transgenic mice. Proc Natl Acad Sci USA 115:1635-1640.

Yang M, Donaldson AE, Jiang Y, Iacovitti L (2003) Factors influencing the differentiation of dopaminergic traits in transplanted neural stem cells. Cell Mol Neurobiol 23:851-864.

Yang M, Donaldson AE, Marshall CE, Shen J, Iacovitti L (2004) Studies on the differentiation of dopaminergic traits in human neural progenitor cells in vitro and in vivo. Cell Transplant 13:535-547.

Yu J, Vodyanik MA, Smuga-Otto K, Antosiewicz-Bourget J, Frane JL, Tian S, Nie J, Jonsdottir GA, Ruotti V, Stewart R, Slukvin II, Thomson JA (2007) Induced pluripotent stem cell lines derived from human somatic cells. Science 318:1917-1920.

Zeng X, Cai J, Chen J, Luo Y, You Z, Fotter E, Wang Y, Harvey B, Miura T, Backman C, Chen GJ, Rao MS, Freed WJ (2004) Dopaminergic differentiation of human embryonic stem cells. Stem Cells 22:925-940. 